The role of operations managers in translating management ideas and practices between firms

Martin Spring* and Christine Unterhitzenberger**

*Department of Management Science, Lancaster University Management School, Lancaster, LAI 4YX, UK

*corresponding author

m.spring@lancaster.ac.uk ORCID 0000-0003-2488-2039

** School of Civil Engineering, University of Leeds, UK.

c.unterhitzenberger@leeds.ac.uk; ORCID 0000-0001-5815-9127 


\title{
The role of operations managers in translating management ideas and practices between firms
}

\author{
The operations improvement literature is found to focus on the adoption of relatively \\ stable, monolithic external management ideas, neglecting the processes by which such \\ ideas and associated practices are identified in source organisations and changed before \\ and during adoption. The notion of translation is used to analyse the way SME \\ managers assimilate practices observed in larger firms during a management \\ development programme. A model of the micro-practices of operations managers \\ during translation is developed. The five micro-practices are: navigating distance; \\ identifying and categorising ideas; interacting with peers; persevering based on \\ reassurance; re-embedding practices. The findings point to the importance of \\ understanding that managers, especially in SMEs, are active in selecting and adapting \\ parts of systemic improvement approaches such as lean, rather than simply choosing \\ and adopting them wholesale. They also underline the importance of peer networking \\ in the translation process. Senior managers who want to adopt management ideas must \\ take account of translation in their strategies. Policy-makers who advocate and evaluate \\ the use of well-known management ideas must also be aware that translation may mean \\ that many useful practices are adopted, even if the adopting firms no longer explicitly \\ espouse the overarching management idea of which these practices are a part.
}

Keywords: operations improvement; operations managers; practices; translation; SME

\section{Introduction}

The operations function has long been a focus for the introduction of ideas and practices from external sources. Notable examples of such management ideas are MRP, TQM, Just-in-Time, lean and six sigma. As each of these has emerged, operations management (OM) scholars have explored the internal logic of the idea and associated practices, and examined implementation challenges and performance outcomes (Boaden 1997; Shrivastava, Mohanty, and Lakhe 2006; Negrão, Godinho Filho, and Marodin 2017). Some proponents of such ideas have claimed them to be universally applicable, for example Schonberger (1986) in respect 
of World Class Manufacturing and Womack et al. (1990) in respect of lean manufacturing. More recent research has argued that a contingency logic is more appropriate, i.e. that contextual and other factors such as firm size should determine which of the practices to implement (Sousa and Voss 2008).

Whether it takes a universalist or a contingency view, however, this research all tends to assume that there is a coherent and consistent form of the particular management idea (TQM, lean, etc) 'out there', external to the firm, which can be brought in to the adopting firm. The task of the operations manager is, according to the OM contingency view, to decide whether the idea fits and then, if it does, to manage the adoption process; taking a more universalist view, the task is centred mainly on adoption.

In this paper, rather than treating the ideas and practices as existing in some disembodied way, external to the firm, we take the view that they exist in the activities that are situated in other, real-life, 'flesh and blood' organisations with whom operations managers interact. As such, we focus on the relationship between the operations manager and the source of the ideas and practices, rather than his or her role in implementing them in the recipient organisation, once they have been selected. Our purpose in this paper then, is to understand how operations managers engaged in operations improvement assimilate what they see and experience in other organisations. We use the concept of 'translation' of ideas (Czarniawska and Joerges 1996) to explore this. Our empirical setting is a management development programme that provides SME managers who have overall operations responsibility with various structured opportunities to engage with larger firms. By joining the SME managers on visits to the large firms, then qualitatively examining the managers' responses to them, we develop a rich understanding of the managers' roles and practices in translating ideas from one organisation to another. 
SMEs are chosen for theoretical, methodological and policy reasons. Theoretically, SMEs are thought to be the main beneficiaries of so-called spillover effects, whereby technological and organisational advances made by large, leading, 'frontier' firms provide some of the means and incentives for smaller, less advanced firms to improve (Andrews, Criscuolo, and Gal 2016) ${ }^{1}$. Methodologically, studying SMEs that have one main operations manager, rather than larger firms with more diffused responsibilities, allows more focussed insight into the way operations managers translate practices from other firms. In terms of policy, governments in the UK and in many other countries are preoccupied with the improvement of productivity (OECD 2015). Since SMEs constitute 99\% of firms in many developed economies, improving SME productivity is essential to this. In the UK, recent policy analyses have pointed to a 'long tail' of low productivity SMEs (e.g. House of Commons 2018), and apply influential evidence that management practices are an important determinant of SME productivity (Bloom and Van Reenen 2010) and that, more generally, management intervention does indeed make a difference to performance (Bloom et al. 2013). Our principal contributions are to show that operations managers are active translators of management ideas and practices from outside their organisations, and to identify five important translation micro-practices that they use in the translation process. We also show that the function and expertise of operations managers makes them uniquely well placed to be active translators of external management ideas and practices. This extends the $\mathrm{OM}$ discipline's conception of the role of operations managers in introducing external ideas and practices, beyond the literature that emphasises operations managers' role in selecting management ideas to fit their organisation's contingencies (Sousa and Voss 2008) or that

\footnotetext{
${ }^{1}$ Such a process has been characterised as 'diffusion' in, for example, recent OECD analyses: in what follows, we explore alternative ways of conceptualising the transfer of practices between firms.
} 
identifies more general 'critical success factors' for implementation of ideas (e.g. Wali, Deshmukh, and Gupta 2003) in OM.

The paper is organised as follows. In the next section, we introduce the main theoretical background, including the central concept of translation. After outlining the method, we set out and analyse the main findings, structured according to five translation micro-practices of operations managers. We then discuss the main theoretical, practice and policy points emerging from the analysis, before concluding.

\section{Theoretical background}

\subsection{Management ideas - terminology}

We will use the term 'management idea' (Sturdy et al. 2019) to refer to a consciously constructed and labelled set of principles and methods, intended to improve performance in a particular area of organisational activity: examples include TQM, lean and six sigma. Although their preferred term is 'management concept', Benders \& Verlaar (2003: 757) use a similar definition 'a more or less coherent, prescriptive vision on (aspects of) organization design'. Paralleling Sturdy et al. (2019), we will use 'practices' to refer to subsidiary components of such ideas: for example, value-stream mapping is a practice that is part of the management idea of lean. In adopting this terminology, we differ from Sousa and Voss (2008) who, in their seminal OM contingency theory research, use the term 'practices' to refer to TQM, JIT and their ilk, i.e. what we are referring to in this paper as management ideas. The convention we do use, however, fits better with the literature on translation, which forms the main theoretical basis for the research. 


\subsection{Operations management ideas: from 'Japanisation' to contingency}

Since the 1980s, especially in North America and Europe, a succession of management ideas such as JIT, TQM, lean and six sigma have been important in the operations improvement agenda - in practice and in the OM literature (Olhager 2002; Shrivastava, Mohanty, and Lakhe 2006; Negrão, Godinho Filho, and Marodin 2017; Zhang et al. 2015). Many of these ideas came from Japanese manufacturing in the 1980s and 1990s, when it enjoyed success in the automotive, consumer electronics and other key sectors. Initially, the OM literature often framed this issue as the 'Japanisation' of western industry, and explored whether seemingly alien ideas could or should be transferred to a Western context (e.g. Voss and Robinson 1987). Then, Schonberger (1986) in relation to 'World Class Manufacturing' and Womack et al. (1990) in relation to lean argued that these ideas are universally applicable. Subsequent research examined how ideas such as these could most effectively be adopted; studies into success and failure were concerned with whether the adoption process was effectively managed (e.g. Chang and Lee 1996), rather than whether the idea was appropriate to the firm and operation in the first place. Then, OM research taking a contingency view (Sousa and Voss 2008) argued that ideas needed to be selected based on their fit with a number of characteristics such as firm size, strategic goals and 'environmental contingencies' (Ketokivi and Schroeder 2004). A recent elaboration of this view proposes taking a more holistic, integrated "organisational system" view, rather than considering each characteristic separately (Romero-Silva, Santos, and Hurtado 2018).

Although contingency-oriented research questions the appropriateness of the various ideas, it continues, like earlier research, to treat them as coherent and consistent, 'out there' in the market of ideas, waiting to be evaluated, chosen and implemented. Most of these ideas exist as sets of principles, techniques and methods promulgated by consultants and business schools; some elements may be captured in practitioner books and websites, as well as in 
more official sources such as the ISO 9000 series of standards for quality management (Mol, Birkinshaw, and Foss 2019). The best-known have all originated, and been practised, shaped and named in particular organisations: lean (as the Toyota Production System) at Toyota (Holweg 2007); TQM in the US military; Six Sigma at Motorola. Only then have they been re-cast as ideas that potentially have wider applicability (Morris and Lancaster 2006; Mol, Birkinshaw, and Foss 2019). For this reason, as ideas move from firm to firm, it is important to pay attention to the source firm at each step, as well as to the adopting organisation and its efforts to implement the ideas. We turn to that process in the following section.

\subsection{Translation of management ideas}

This section reviews alternative ways to think about the spread of ideas and practices between organisations, focussing in particular on the notion of translation. As a point of reference, it begins with perspectives that, like the OM literature summarised above, pay little attention to how the idea or practice exists: it is 'out there', external to the recipient firm. We then develop the discussion to take more account of the source, as well as the recipient, and the translation of ideas between the two.

At the macro level, diffusion is a dominant metaphor in the literature on the spread of ideas. This perspective draws on Rogers' (2003) seminal work on the diffusion of innovations. Rooted in studies concerning new products and technologies, it tends to treat the innovation as unvarying as it moves from one actor to another, and emphasises the communication processes and social system by which innovations are promoted and passed on (Zhu, Tian, and Sarkis 2012). This perspective influences policy analyses: a recent OECD ${ }^{2}$ study claimed that the transfer of best practices from leading 'frontier' firms to SMEs had

\footnotetext{
${ }^{2}$ Organization for Economic Cooperation and Development
} 
diminished since the global financial crash of 2008, and characterised this as a 'broken diffusion machine'(OECD 2015: 12) ${ }^{3}$.

Other approaches focus on the would-be adopting firm, using concepts such as absorptive capacity (Cohen and Levinthal 1990) and dynamic capabilities (Teece, Pisano, and Shuen 1997) to characterise a firm's effectiveness in assimilating and using new knowledge, by virtue of the firm's existing knowledge, strategies, organisational structure and processes. These characteristics are typically treated as aggregate properties of the firm, although some analyses recognise that absorptive capacity may depend on the counterpart from whom the absorption is taking place (Lane and Lubatkin 1998). Even studies exploring the microfoundations of absorptive capacity are still concerned with rather generalised, firmwide sub-components of the phenomenon, rather than the more concrete activities of managers (Lewin, Massini, and Peeters 2011).

Although diffusion and adopting-firm perspectives differ in their emphasis, both treat the innovation in question as relatively stable during the diffusion or adoption process. In contrast, Ansari, Fiss and Zajac (2010) argue that ideas (they use the term 'practices') are not simply adopted, but are adapted to the recipient organisation, to achieve technical, cultural and political fit. The degree of adaptation is also affected by characteristics of the idea being adopted or adapted: its interpretive viability (the extent to which it is open to multiple interpretations), its divisibility (whether it can be implemented independent of scale) and its complexity (Ansari, Fiss, and Zajac 2010). This approach, then, takes account of the interaction between the idea and the recipient organisation, and the mutual adaptation that results from this. But it does not explore the relationship between the idea and the originating

\footnotetext{
${ }^{3}$ In fact, this report mentions diffusion seven times in its one-page Foreword, which argues as follows: "However, the gap between those global leaders and the rest has increased over time, and especially so in the services sector. This implies that knowledge diffusion should not to be [sic] taken for granted. Future growth will largely depend on our ability to revive the diffusion machine, both within and across countries." (OECD 2015: 3)
} 
organisation; indeed, Ansari et al. merely refer to 'an external practice' (Ansari, Fiss, and Zajac 2010: p 2010), without considering where it is performed and how the particular originating site is implicated in the process of transfer, adoption or adaptation. In contrast, some of the literature that uses the notion of translation, to which we turn now, more evenly considers the relationship between the practice and both the originating and recipient organisations.

The seminal source on translation in this sense is Czarniawska and Joerges (1996). Their central argument is that an idea that is deployed in a particular set of practices in one organisation (the originating firm) has to be disembedded before it can 'travel' to another organisation, where it is then re-embedded. In their review of translation, Wæraas and Nielsen (2016) argue that this early work of Czarniawska and Joerges is particularly notable for 'treating disembedding and re-embedding on an equal footing' (Wæraas and Nielsen 2016: 246). Research in other streams of translation research - and, indeed, later work by Czarniawska and Joerges - gives much greater prominence to the re-embedding stage, in the same way that the OM literature concentrates on adoption. Wæraas and Nielsen also note the early emphasis on the brokering role of the actors in translating ideas from source to recipient, and the 'distinct semiotic processes going on in the source context before a construct [idea] begins its journey....' (Wæraas and Nielsen 2016: 248). This perspective is thus especially well-suited to our focus on individual managers and how they assimilate ideas encountered in other organisations.

According to Czarniawska and Joerges, the idea, once disembedded, becomes an object - a text, image, prototype, etc - that can travel, then be given attention by the recipient organisation, and incorporated into new or altered practices within it. Crucially, in the process, the idea is translated, in the sense that the people receiving the object understand it in different ways and 'may act in different ways, letting the [object] drop, or modifying it, or 
deflecting it, or betraying it, or adding to it, or appropriating it' (Latour (1984: 267), cited in Czarniawska and Joerges (1996: 23)). Sahlin-Andersson (1996: 82-88) argues that an important part of this is 'editing', whereby the idea is retold differently in each situation, according to the particular context, in an appropriate formulation for the intended audience, and in a way that presents a logic of causality concerning the idea's adoption and the consequences thereof.

The notions of attention, distance and framing are important. Attention is concerned with why and how actors devote time, thought and effort to particular ideas, amidst the myriad possibilities that face them. Many ideas are circulating 'most of the time, at least in some places' (Czarniawska and Joerges 1996: 26): for example, the basic principles of process improvement and employee engagement have been advocated for decades. To give attention to an object, people need to be able to identify and categorise it in some way: "we cannot translate what is wholly unrecognisable' (Czarniawska and Joerges 1996: 28). Interaction with the idea may also affect the recipient: 'we approach an idea in terms of what we already know.... the act of discovery creates a new idea and new actor' (Czarniawska and Joerges 1996: 28-29). Distance is important because, according to Morris and Lancaster (2006: 210), greater geographical or contextual distance demands more translation, through 'repackaging and simplification into tools and techniques', possibly through several iterations. A manager's attention and perception of distance also depends on framing. The literature on framing is vast and varied (Cornelissen and Werner 2014), but a recurring feature of definitions, particularly at the micro level of the individual manager, is that a frame is a 'knowledge structure that directs and guides information processing'(Cornelissen and Werner 2014: 184). Either as a consequence of their mental models or schemas (Prahalad and Bettis 1986), or more deliberately for their own strategic reasons, different managers will frame phenomena in different ways. This can determine the way a manager sees a problem 
situation in her own firm, or a management idea or set of practices deployed in another. This in turn depends on the interpretive viability (Benders and Van Veen 2001) of the idea: for example, lean has sufficient interpretive viability that it could be framed as a cost-reduction idea by one manager, and as a vehicle for organisational learning by another.

Attention, distance and framing are partly social phenomena. Individual managers may see and identify an idea-object but, to do so, need to place it in relation to other ideas, practices in their own organisation, and in the context of relationships of which they are a part. More specifically, even though the principle of process improvement has been circulating for decades, for any particular form of process improvement to be received and translated into practice, it needs to come to the attention of and be identified by a would-be recipient, then be institutionalised by being seen as relevant to a wider network of actors, within and outside the organisation.

A central claim of the translation literature is that ideas are always translated, never copied exactly, when they move from one context to another (Røvik 2016: 292): they exhibit variation. But different authors understand the reasons for and modes of variation differently. van Grinsven, Heusinkveld and Cornelissen (2016: 276-77) argue that there are two dimensions of variation: the source of variation and the object of variation. Source variation can arise through embeddedness, whereby an idea is made to fit its recipient context, or through strategizing, which emphasises the agency of the broker in using variation deliberately to achieve political outcomes in their organisation. Object variation can be either representational or structural. Representational variation emphasises the changes in language and symbols used, with the material practices remaining relatively unchanged. Structural variation is the opposite: the material practices change, while the language and symbolism remain stable. 


\subsection{The role of the manager in translation}

Another important claim of the translation literature is that actors work on and change the ideas they encounter, rather than being passive carriers. Nevertheless, recent work has bemoaned the lack of attention paid to the micro-practices of managers as they do this (Mol, Birkinshaw, and Foss 2019; Werr and Walgenbach 2019). Røvik (2016) proposes that such a focus can be used to develop a prescriptive, instrumental theory on how managers can translate more successfully, treating the process of disembedding from the source organisation as just as important as translation to the recipient units. Huising (2016) stresses the importance of understanding how managers move between the external world of management ideas and the internal world of implementing change, and adopts an 'inhabited' perspective on how managers 'exert significant influence via their choices and plans' (Huising 2016: 385) on how externally-sourced management ideas will be re-embedded in their organisations. Huising's emphasis on managers' choices echoes Mantere's (2008) reassertion of the agency of middle managers, in spite of the potentially constraining effect of their role expectations. Radaelli and Sitton-Kent (2016) focus specifically on the practices of middle managers in the translation process. Their framework gives prominence to the practices of middle managers in idea acquisition and in what they term appropriation of the translation role ${ }^{4}$ (after Phillips, Sewell, and Jaynes 2008). Idea acquisition involves the accessing and merging of diverse types of knowledge, such as scientific sources, internal process knowledge, ideas from other organisations; connecting the information to others, such as senior managers, employees, peers, suppliers; and using and merging different types of enquiry e.g. formal meetings and seminars, informal chats, explorations and experiments. Appropriation of the translation role involves making sense of the idea to be translated;

\footnotetext{
${ }^{4}$ Terminology adapted slightly from the source, to aid clarity.
} 
making sense of the context e.g. gauging the receptiveness of senior management or other staff; and building the manager's identity in relation to the translation.

Radaelli and Sitton-Kent's review also presents something of a contradiction: the influence of senior management is seen as especially important in the 'appropriation of the translation' role. This is also supported by Soltani et al. (2012), who suggest that middle managers are often forced to focus on narrower and more short-term practice improvement aspects due to the approach of senior management. And yet some of the studies reviewed (e.g. Balogun and Johnson 2004) show that middle managers undertake radical translations even in the absence of contact with senior managers (Radaelli and Sitton-Kent 2016: 319), using instead lateral contacts with peers and other employees in the translation process.

Our review, then, suggests that the notion of translation is a useful way to understand how organisations identify and use ideas for operations improvement. Furthermore, the relatively recent research on the translation micropractices of managers has potential to complement contingency-based OM research, which frames the operations manager's role as a rather abstract process of selecting among pre-defined ideas depending on high-level characteristics of the operation and firm context. None of the empirical studies on middle management that we review here relates specifically to the operations function, but they are nevertheless relevant. And not only are they relevant, they offer a way to compensate for the more general lack of treatment, in the operations management literature, of the roles and management practices of operations managers (Spring 2017). Many of the SME managers in our study are middle managers; some (especially from very small firms) are General Managers or Managing Directors, but have direct overall responsibility for operations. As such, we address the following research question:

How do operations managers identify and translate operations improvement ideas from other organisations into their own organisations? 


\section{Method}

\subsection{Research Design}

We chose to adopt a qualitative design, for several reasons. Since our basic starting assumption is that management ideas are translated - to the extent that they may be re-named, lose any widely recognised labels, or become substantively altered during translation - a survey-based approach using existing scales based on particular management ideas and associated terminology (such as TQM) would not allow us to identify the issues of concern. Furthermore, since we are interested in understanding a process - translation - and the practices of managers, we needed to explore qualitatively with the participants their interpretations and responses to the ideas and practices they encountered. More specifically, we followed a cohort of managers on a management development programme for SMEs, the broad theme of which was enhancing firm productivity by improving the management of people. A central feature of the programme was engagement with three large firms, all of whom were international corporations from engineering-intensive manufacturing, with revenues in the billions of Euros. The main vehicle for engagement with them was a group visit to one manufacturing site of each. These visits included presentations by the large firms' managers, site tours and observations. The participants were formed into small group 'action-learning sets', within which they discussed particular themes from the programme, including the visits. Our empirical focus was the series of large-firm visits.

The structured engagement allowed us to examine aspects of the translation process as it happened. The managers were somewhat self-selecting because their participation in the programme suggested a predisposition toward change and improvement; on the other hand, they were willing participants, with whom we had developed a level of trust and openness. As such, the unit of analysis is the manager although we do not see the translation as a 
solitary, purely cognitive process, but a socio-technical process situated in the physical, technological, organisational and social context of both the host and recipient organisations. We do not seek to characterise and compare individual managers but, by exploring the responses of the managers to the opportunity to engage in translation, we seek to understand common themes in their translation practices.

\subsection{Data collection}

We conducted one-to-one, semi-structured interviews with the SME managers who participated in the management development programme. Fifteen managers were interviewed, and Table 1 provides basic information about them. Most of the participants held job titles such as Operations Manager or Operations Director; a few were general managers with a central operations responsibility. The numbers of employees in the firms ranged from 15 to over 200, with the vast majority being under 100 . The interviews lasted between 25 and 60 minutes, totalling 465 minutes of audio recording. The recordings were transcribed.

We emphasised that the interviews were neither part of the management development programme nor an assessment or evaluation of performance. We used a semi-structured interview guide with 12 standard questions, and follow-up questions based on the interviewee responses. Our questions covered five key areas: 1) background and prior experience of the interviewee; 2) expectations prior to the site visits; 3) significant and interesting observations during the visits; 4) relevance of observations to interviewees' own practices and 5) peer support and mentoring. The primary data source was the interview itself but, as we usually conducted the interviews at the participants' premises, we toured and observed the premises and the activities taking place on site, where possible. We used notes from these tours as supplementary data on the relevance of observations and adoption of practices. One of the researchers also accompanied the cohort on the site visits to the large firms, to see and hear 
what was presented and observe the participants' responses. The agendas from these visits and incidental notes taken enabled the researchers to ask appropriate interview questions.

\begin{tabular}{|c|c|c|c|c|c|c|}
\hline Code & Position & Responsibility & Background & Industry & $\begin{array}{l}\text { Work } \\
\text { experience }\end{array}$ & $\begin{array}{l}\text { Company } \\
\text { size } \\
\text { (employees) } \\
\end{array}$ \\
\hline OM1 & $\begin{array}{l}\text { Production } \\
\text { manager }\end{array}$ & Operations & $\begin{array}{l}\text { MSc level } \\
\text { (technical) }\end{array}$ & $\begin{array}{l}\text { Micro } \\
\text { engineering }\end{array}$ & 12 years & 40 \\
\hline OM2 & $\begin{array}{l}\text { Operations } \\
\text { director }\end{array}$ & Operations & Training courses & $\begin{array}{l}\text { Manufacturer of } \\
\text { bespoke cups }\end{array}$ & 9 years & 49 \\
\hline OM3 & $\begin{array}{l}\text { Manufacturing } \\
\text { manager }\end{array}$ & Operations & $\begin{array}{l}\text { Degree level } \\
\text { (management) }\end{array}$ & Food production & 12 years & 216 \\
\hline OM4 & Chief Executive & Operations & $\begin{array}{l}\text { Degree level } \\
\text { (management) }\end{array}$ & $\begin{array}{l}\text { Transportation } \\
\text { (ferry) }\end{array}$ & 25 years & 68 \\
\hline OM5 & $\begin{array}{l}\text { Operations } \\
\text { manager }\end{array}$ & Operations & $\begin{array}{l}\text { Degree level } \\
\text { (technical) }\end{array}$ & $\begin{array}{l}\text { Manufacturer of } \\
\text { magnetrons }\end{array}$ & $>15$ years & 35 \\
\hline OM6 & Managing director & Operations & $\begin{array}{l}\text { Degree level } \\
\text { (technical) }\end{array}$ & $\begin{array}{l}\text { Software } \\
\text { developer }\end{array}$ & 14 years & 45 \\
\hline OM7 & $\begin{array}{l}\text { Founder and } \\
\text { owner }\end{array}$ & Operations & Training courses & $\begin{array}{l}\text { Manufacturer of } \\
\text { farming products }\end{array}$ & 40 years & 15 \\
\hline OM8 & $\begin{array}{l}\text { Production } \\
\text { manager }\end{array}$ & Operations & no degree & Quarry & 30 years & $>30$ \\
\hline OM9 & $\begin{array}{l}\text { Engineering } \\
\text { manager }\end{array}$ & Operations & $\begin{array}{l}\text { MEng level } \\
\text { (technical) }\end{array}$ & $\begin{array}{l}\text { Hardware } \\
\text { developer and } \\
\text { installer }\end{array}$ & 11 years & 15 \\
\hline OM10 & $\begin{array}{l}\text { Co-founder and } \\
\text { director }\end{array}$ & Operations & $\begin{array}{l}\begin{array}{l}\text { Degree level } \\
\text { (technical) }\end{array} \\
\end{array}$ & $\begin{array}{l}\text { Software } \\
\text { consultancy }\end{array}$ & $>30$ years & 80 \\
\hline OM11 & $\begin{array}{l}\text { Director and } \\
\text { general manager }\end{array}$ & Operations & $\begin{array}{l}\text { Degree level } \\
\text { (unrelated) }\end{array}$ & $\begin{array}{l}\text { Manufacturer of } \\
\text { specialist } \\
\text { insulation } \\
\text { products }\end{array}$ & 15 years & 45 \\
\hline OM12 & $\begin{array}{l}\text { Operations } \\
\text { director }\end{array}$ & Operations & $\begin{array}{l}\text { MSc level } \\
\text { (management) }\end{array}$ & $\begin{array}{l}\text { Engineering } \\
\text { company }\end{array}$ & 16 years & 31 \\
\hline OM13 & Managing director & Operations & $\begin{array}{l}\text { Degree level } \\
\text { (technical) }\end{array}$ & $\begin{array}{l}\text { Manufacturer of } \\
\text { glassware }\end{array}$ & $>30$ years & 28 \\
\hline OM14 & $\begin{array}{l}\text { Head of } \\
\text { Manufacturing }\end{array}$ & Operations & $\begin{array}{l}\begin{array}{l}\text { Degree level } \\
\text { (technical) }\end{array} \\
\end{array}$ & Food production & $>30$ years & \\
\hline OM15 & $\begin{array}{l}\text { Operations } \\
\text { director }\end{array}$ & Operations & no degree & $\begin{array}{l}\text { Manufacturer of } \\
\text { doors }\end{array}$ & 7 years & $>30$ \\
\hline
\end{tabular}

Table 1 - SME managers interviewed

\subsection{Data analysis}

We analysed the interview data using thematic analysis, which entails a rigorous process of familiarisation, coding, theme development and revision (Braun and Clarke 2006; Clarke and Braun 2017). This allowed us to identify patterns of meaning across the dataset. The analysis was undertaken manually without the support of a specialised software, which allowed us to fully immerse ourselves in the data. This was appropriate to the relatively simple data structure 
(i.e. multiple interviews with people in essentially the same roles) and modest number of interviews.

Overall, 435 significant statements were identified. We used open coding to identify initial themes, then axial coding to identify themes that related to each other, resulting in a number of 'first order themes', examples of which are shown in the data structure diagram in Appendix 1. For example, one initial theme was 'dispelling myths' (i.e. SME managers' realising that the large firms were often not as sophisticated as anticipated), but, as we reviewed and refined themes (Braun and Clarke 2006: 91) by axial coding, in dialogue between us, this eventually became part of the first order theme of 'rationalising difference'.

We used an abductive process (Mantere and Ketokivi 2013) drawing mainly on translation theory. Other theories concerning the transfer of operations practices between firms, such as diffusion, focus on firm-level phenomena and, as we have seen, treat ideas and practices as unchanging: neither of these were appropriate to our data. Dubois and Gadde (2002) point out that the abductive process requires iteration not only between theory and empirical data, but also between the framework and the case. In our study, it became increasingly evident that the operations manager was the unit of analysis (or case, in Dubois and Gadde's term), rather than, say, the firm or the management idea, and so the most appropriate theory would be one that was concerned with individual managers' roles and practices (cf Van Maanen, Sörensen, and Mitchell 2007). This led us to draw more on those parts of translation theory concerned with the individual manager, especially the notions of attention (Czarniawska and Joerges 1996), editing (Sahlin-Andersson 1996), variation (either representational or structural) (van Grinsven, Heusinkveld, and Cornelissen 2016) and the appropriation of the translation role (Radaelli and Sitton-Kent 2016). Continuing the example from the previous paragraph, we combined the first-order theme of rationalising difference with the theoretical notion of distance (Morris and Lancaster 2006), but, being concerned with the practices of managers 
rather than the more generic characteristic of 'distance', developed the micro-practice of 'navigating distance' (see Section 4).

\section{Findings and analysis}

We analyse the translation micro-practices of the SME operations managers, particularly in respect of their engagement with the originating firms, i.e. the large firms they visited. We identify five translation micro-practices: navigating distance, identifying and categorising ideas and practices, interacting with peers, persevering based on reassurance, and reembedding of practices. In what follows, we will refer to the participants as 'managers' or 'SME managers': where we wish to refer to managers from the large firms, we will make that clear. We use selected illustrative quotations, indicating the respondent by number ("OM2" etc.) from Table 1 . When interviewees refer to the large firms by name, we anonymise these by using 'Corp1', 'Corp2' and 'Corp3'.

\subsection{Navigating distance}

Navigating distance involves simultaneously acknowledging various forms of distance and, sometimes, seeking ways to overcome it. Managers characterise and assess the distance, rationalise it (e.g. by justifying to themselves and others why certain practices would or would not be appropriate for them), and then find ways to either live with it or reduce it. Of necessity, it requires managers to 'look both ways': they need to compare the contexts and practices of both the source and recipient organisations. The managers in our study navigated the distance in somewhat contradictory ways. At the outset, before the site visits, they perceived significant distance. Although they often knew very little about the large firms, managers often anticipated that they would broadly be adopting more 'modern' 
approaches, be in some ways 'advanced' and innovative, and to have very different challenges and problems to their own.

It's like going to see the Queen. You don't go in there, she's got her tracksuit bottoms on type of thing. You expect it to be really gleaming, don't you.... [OM 5]

[Corp3], well, [Corp3], you think state-of-the-art and modern, because that's just the perception you get of a company with a name like that.... It's just, obviously, what you get in your mind. [OM15]

Mostly, managers' expectations concerned technological and physical aspects, rather than management. One of very few comments that did mention management issues was as follows:

I was expecting to see best practice and some ideas and some new ways of thinking and new ways of doing things that would inspire, hopefully, us to see how we could maybe do things in our business that would change the way we work. [OM6]

The managers had varied levels of experience of management ideas such as lean. Many had little or none, and did not perceive them to be relevant because of the (small) size of their operation or the sector they operated in. Many associated improvement with digitisation, with several commenting that they could see the benefit, but saw implementation as too expensive: given a 'clean piece of paper' [OM8], they would implement lean methods and digitisation, but changing an established operation was seen as too difficult.

Once they engaged with the large firms, the managers focussed less on technological sophistication and more on management and organisation. Perceptions of distance remained, but managers worked to make sense of the sources of distance, mainly in terms of business 
and organisational factors, and formed views on how much they could emulate the large firms' practices, given their size, resources or particular sector.

...you go to these places and think 'they've probably got it right and it's just a case of how can we get towards that?' We're never going to be exactly like them because we're never going to have their resources and even the money involved, we're in a very small margin business and it can go very badly wrong very quickly for us if you have one bad month. [OM 4]

After their initial engagement with the large firms, however, many of the managers perceived a greater similarity to their own firms than first anticipated. Respondents who told us that they expected rather idealised, 'state-of-the-art' facilities often noted that this was not what they actually encountered. For example, the respondent who likened the prospect of one of the site visits to 'going to see the Queen' then commented:

You expect it to be really gleaming, don't you, and it wasn't - and I think that was better, really, because we got a better feel [OM5]

Several other respondents similarly felt that the lack of 'polish' and sophistication reduced the distance, because it was closer to their own experience. Others saw the perceived shortcomings of the large firms in a more negative light, noting poorly utilised space, an apparent lack of productive activity, rather ordinary production processes, and so on.

The one thing I was surprised at, at [Corp2], was the amount of empty buildings. There were absolutely acres of empty buildings. You walked in a building and most of it was completely empty, with just a bit of something at one end. If only I could have a proportion of that? We could make such good use of it. [OM7] 


\subsection{Identifying and categorising ideas and practices}

Identification involves isolating particular management ideas, practices and more general principles, as candidates for further translation. It is implicitly combined with categorisation: managers form conjectures as to which ideas and practices could complement and enhance operations in their own organisations. Our managers identified a mixture of ‘material, working practices' (cf. Morris and Lancaster 2006), and much more general, abstract principles that they had observed in the large firms. They did not, however, seek to translate or adopt integrated management ideas such as lean.

The managers referred to specific practices identified as 'little nuggets', or 'little things'. For example, several of them started to use whiteboards to display production targets and outcomes, to be used in short meetings held frequently (e.g. every day or every shift), with production staff. Indeed, the set of whiteboards used at one of the large firms generated so much interest that some of the managers arranged a follow-up visit to explore them further. One of many other examples of specific practices was as follows - very precisely specified and attributed to a particular presenter at one of the large firms:

... the daily stand-ups.. (this was [names individual] actually), '...what have you done yesterday and what are you going to do today, and what are you stuck with?': so that would be quite good wouldn't it? [OM2]

Other initiatives identified included a suggestions scheme, combining targets for the number of suggestions each employee should make with small but well-publicised financial rewards. More generally, communication was central:

So, yes, for me, the two key things that came out is communicate more and better with your staff and have a two-way bottom-up approach more in terms of ... and I know a 
suggestions scheme is just one small part of that but we don't do an awful lot of bottomup stuff. [OM4]

Since one of the researchers joined the site visits, we know that some ideas and practices featuring prominently in the visits (e.g. agile product development) did not figure in our interview data: lacking relevance and feasibility in the managers' worlds, they were apparently disregarded (although some small elements of the practices were adopted). Two of the large firms demonstrated the use of shop floor production control whiteboards: in one case this was part of the Japanese-influenced '[Corp1] Production System' (complete with Japanese terminology such as 'Gemba' and 'hoshin kanri'); in the other, as part of a more general theme of 'communications'. However, the SME managers discarded the wider system and the Japanese terminology as they identified the practice (i.e. using whiteboards) for incorporation into their own operations. Similarly, the daily stand-up meetings already mentioned were abstracted from the agile product development process in which they were first encountered on the visits.

The literature on OM approaches such as JIT is critical of what is sometimes derogatorily termed 'cherry-picking' i.e. taking practices out of context without taking account of the interdependencies between them (e.g. Lillrank 1995). In some instances, such criticism may be valid e.g. in JIT manufacturing, drastically reducing batch sizes typically requires reduced changeover times through practices such as $\mathrm{SMED}^{5}$. But some practices can be 'cherry-picked': many of those evident from our data are associated with communications and engagement, rather than being structural production process issues. One of the managers exemplifies this focus on selected, relatively basic improvement ideas:

\footnotetext{
${ }^{5}$ Single-Minute Exchange of Dies
} 
...it's baby steps and just picking off little nuggets of information and trying to implement them. Yes, I definitely picked off one, which has led to an actual change and is now a system that is in place at our work. It's very basic but I never thought of it before, [OM 11]

One of our interviewees was quite explicit in adopting a cherry-picking approach:

I love cherry-picking... I used to ride horses; I used to have four different teachers and I would go to each one and I would take out what would relate to me, to make my own package if you like, you know, so I've always been like that. I'll take out what relates to me, what I like, and then I'll go somewhere else and do the same thing; so, yes, I'm a big cherry-picker. I think if you get too focused on doing, you know, saying 'oh well you know, this person's the best', you're losing out possibly on other things. [OM2]

The managers may have cherry-picked because their relatively brief engagement with the large firms only allowed them to assimilate practices and principles in a piecemeal way. However, none of our data suggest that the managers were seeking management ideas such as lean, nor did they express a desire, given more time, to implement such ideas:

It's been noted that I've changed personally throughout the course. I think the department is working better now through leading, you know, becoming a leader. That's improving productivity. I've not improved productivity by lean, agile, or any of the... you know. [OM9]

As well as specific practices, managers identified general principles or patterns of managerial conduct that they could use and adapt. People-related issues were important, and this was indeed a deliberate focus of the engagements with the large firms. The top management team of one large firm was notable for its open, transparent and inspirational leadership style: 
“"I think [Corp1], we were told it was a world-class facility. The one thing I really liked about [Corp1] was [names MD], is he the MD or CEO? Very inspirational. I think people would like to aspire to be him....You watched him, you watched his people, and all of these people were just - I'm not saying in awe, but they were all on every word. They trusted what he did. [OM 14]

As well as emphasising a policy of transparency in the way they managed, this firm were also (apparently) transparent about some of their own challenges:

Whereas, when I went to the [Corp1] one, how open they were. The fact they did presentations and they showed us in action, it was fantastic the way they did it. They were just so open about the problems they had.... [OM12]

Some other wide-ranging aspects were more difficult for the managers to access. These were sometimes associated with deep-seated facets of organisational culture and people management, aspects that were more difficult to demonstrate than practices such as visual management and particular forms of meeting or organisation structure. Two responses exemplify this interest in learning more about the management of change and coordination:

I guess what we didn't get out of it, necessarily, was how you get everybody in the company on that journey, which in somewhere the size of [Corp2] must be very, very hard." [OM 10]

"I thought that was good, the cross functional teams. I'd love to know how they manage non-co-located teams though, you know; we struggle shift to shift, let alone in different countries" [OM2] 


\subsection{Interacting with peers}

Interaction with peers can occur within managers' own organisations, or with equivalents in other organisations. In our case, peers from other firms provided the main opportunity, serving as sounding-boards in discussion regarding management ideas and practice to which they had all been exposed, as well as supplementary sources of ideas and practices. Managers found that they were often able to learn more from each other than from any simple 'adoption' of ideas or practices from the large firms' examples. Despite their firms being in different sectors and markets, the managers found that they often faced the same problems. Speaking about his/her fellow participants, one manager said:

...everyone is from totally diverse, different company and diverse backgrounds. But everyone, we found out on the first two days, has got exactly the same problems, and that, nine times out of ten, comes down to people problems and things, how to get the best out of your team. [OM5]

On the other hand, seeing practices in each other's very different contexts provided new insights and again inspired them to adopt 'little nuggets' for their own firm to solve similar underlying problems. These solutions were sometimes very concrete and specific, such as the direct copying of a particular administrative document format:

We had an appraisal which was 17 pages long. [name] had an appraisal for his engineers which was two pages long. I was like, 'Okay, that's the one I want.' [OM14]

The establishment and development of peer-group action learning sets, as part of the programme, helped this process of mutual learning:

Honestly, the best bit for me so far has been talking to other businesses in the fairly safe environment... [OM4] 
Although it is difficult clearly to identify cause and effect, our data suggest that the visits to large firms influenced the topics on which peer-to-peer interaction focused. So, even though managers did not seek to directly adopt, say, a particular visual management technique from a particular large firm, the fact that they had been exposed to this during the visits led to peerto-peer conversations on that subject. One example related to the creation of FMEA (Failure Mode and Effect Analysis) documents:

[the Corp3 manager] got out some template FMEAs and [Corp3] notes...The only unfortunate thing is, they're [Corp3] notes. They're just huge, bureaucratic things... That was part of the challenge, trying to dig down to, 'What do I actually need to do out of all that paperwork?' (...) Someone on the course mentioned they do design FMEAs, so then I have spoken to him outside the course since then and he's given me his template FMEA, which is much better. I can see it is. (...) Yes. So, between the two, the [Corp3] and his... I'm going to come up with a [names his firm] FMEA [OM 9]

This suggests that translation is not always a direct, dyadic phenomenon, but can operate through indirect processes across a wider network.

The opportunity the course gave managers to reflect more was a benefit in itself. But, in a more specific way, the chance to compare perceptions of similar problems and solutions with peers enhanced exploration of new practices, and validation for experiments that the managers conducted:

But actually, having that time out of work gives you perspective and helps a great deal. When you're just getting these little things just dropped on you, so try this, have a look at this, think about this a different way, a lot of that was very, very good. A lot of it about the understanding other people's perceptions of the same problems was very good as well. [OM 14] 


\subsection{Persevering, based on reassurance}

Identifying ideas and practices, sometimes served to convince managers to continue with practices that they already had in place in their own organisations, or to persevere with new initiatives to embed ideas and practices. This results from the 'dialogue' between existing practices and those with potential to be added, while navigating distance and identifying ideas and practices, and from finding reassurance in what they observed, as well as through peer interaction. For the managers in our study, finding that the large firms' facilities were not extraordinarily sophisticated did more than make them approachable and accessible: it also meant that the managers reflected in a different way on their own operations. Often, managers noted that the large firms faced problems they could easily recognise from their own operations, and often used similar practices to deal with them, which engendered more confidence in what the managers were doing within their own firms:

And coming from a smaller company, although I've been around a bit, a lot of people think in a smaller company, 'Oh, we're terrible. We don't work well at all. We have this issue. We have that issue.' But when you see bigger companies have got the same issue but on a gigantic scale, it's like okay, and it makes you feel a little bit better really... [OM 5]

The managers identified several shortcomings in the larger firms' operations. There were three dominant themes: information systems, engagement, and relative agility. In contrast to initial expectations of technological sophistication, the managers were surprised to see extensive use of paper-based information, basic spreadsheet tools and relatively basic hardware, rather than a more digitally sophisticated environment.

'But [Corp3] use spreadsheets, so they actually use Excel to do their... They have this big touch screen, but everything was done in Excel, so it had a lag to it, because as the 
data fills up, it's not really the engine you use for that type of thing. They were just saying, 'Oh there's just some lag to this.' I was like, 'With web apps these days, and database management, I don't understand why you're not shifting to there?' [OM12]

Other shortcomings identified by the managers related to engagement with both suppliers and their own employees ("It felt they could do a lot more with their employee engagement" [OM 6]). They also noted differences in agility and innovation methods, perceiving that, due to rigid structures in the large firms, even small innovations can take a long time.

These insights clearly engendered increased confidence among the managers in many of the initiatives and practices that they were already pursuing. In some cases, this reassurance was transmitted back to their own staff:

...it's been good to go back to my team as well and say, 'Look, I've been in [Corp3] and they've got exactly the same problem we've got there. I've been in to [Corp1] and they're doing what we're doing. In fact, we're doing more process-driven stuff than what they're doing,' [OM 5]

\subsection{Re-embedding of practices in SMEs}

By re-embedding, we mean the incorporation of practices in the context and operations of the recipient firm (consistent with the translation literature). In contrast to the managerial micropractice of persevering, based on reassurance, re-embedded entails bringing in an idea or practice that is new to the operation or, in some instances, re-kindling initiatives that had been abandoned. Our interviews indicate that SMEs re-embedded a range of translated practices. Because we did not closely follow the re-embedding process, we mainly have insights into what was re-embedded, not how. Many of the managers had begun to use 
adapted versions of the structured communications and visual management practices that were very prominent at two of the three large firms. As mentioned, these included whiteboards for production control:

when we went on the tour in his little alcove, that was really good, there was like so much information, like when you walked in it sort of hurt your eyes because there was so much.... so that big empty whiteboard that you might have seen when we walked in - we're going to start looking at capacity per machine on a daily basis, and how much we're utilising it.... [OM2]

Some of the managers documented in detail what they had observed and discussed, with a view to using the ideas in future:

The productivity measurement system has changed. You've got a load of other ideas and bits of information. I've got loads of little bits of notes that eventually, parts of it will be used, I would hope. [OM 11]

In other cases, the managers identified and related to principles such as communication and transparency, but developed their own practices as a way to implement the general idea:

I think there was quite a bit on the course around communication, which is leading us to change how we communicate things. So, we've brought in things like we now do a full company meeting every two weeks, which is just really announcements. Then every six months, we do what we call a town hall meeting... We're much more transparent .....with the finances, with KPIs and basically how we're doing. So, we used to tell people we were doing well, but not necessarily tell people when things weren't so good. [OM6]

Alternatively, managers recognised the same purpose in practices they already used, but revised them based on what they observed: 
... it's just presenting information in a really simple way. That ultimately is all that was needed. I think I overcomplicated it for years. So that works nicely. [OM11]

Several managers reported that they had reenergised efforts to use particular practices in their firms, encouraged by what they saw the large firms using successfully. These included various forms of suggestion scheme:

One big thing is we used to have a suggestions scheme that people used to buy into, and if your suggestion won then that was the one that was taken forward, etc. That was kind of dropped a couple of years ago, but everybody wants to get it going again. So I said, 'Okay, we'll sort it.' [OM 5]

Where we do have data on the process of embedding, most accounts suggest a receptivity to change:

Then the other week, I got them together, said, "Right, we're going to introduce the SQCDP [performance measures] board again. What do you want to put on it, guys?" And they're like, "Oh, cool," and within the afternoon, I had graphs coming out of my ears, the options....look at this. We're measuring this, and we're measuring more than we need to be measuring but everyone has got the information, just don't get asked for it. So it's like, oh, okay, cool. [OM5]

Of course, these are the accounts of the managers implementing the changes, so may show them in a positive light. But, by virtue of the context of our study in an educational programme, the managers were not obliged to adopt any integrated management ideas. No-one was there to 'sell' or 'buy' a management idea such as lean, and there was no incentive for managers to adopt practices that they did not want to, nor to convey an unduly positive account to us as researchers. 


\subsection{A framework for operations managers' micro-practices}

The five micro-practices are summarised in Figure 1. The translation process sees operations managers exposed to ideas and practices in the source organisation, which have varying degrees of interpretive viability, and are presented and represented in particular ways. They are also exposed, explicitly or implicitly, to more general principles such as 'transparency'. They perceive the ideas and practices in source organisations in relation to the current and dormant practices in their own (recipient) organisation and its wider context. While we do not see the five micro-practices as strictly sequential, navigating distance and identifying ideas and practices are more prominent before and during the encounters with the source.

Interacting with peers, in our setting, took place after the initial encounters, providing further perspectives on what had been observed, and supporting managers' process of reflection. Persevering and re-embedding followed, as managers decided what to retain in their operation, and what to add.

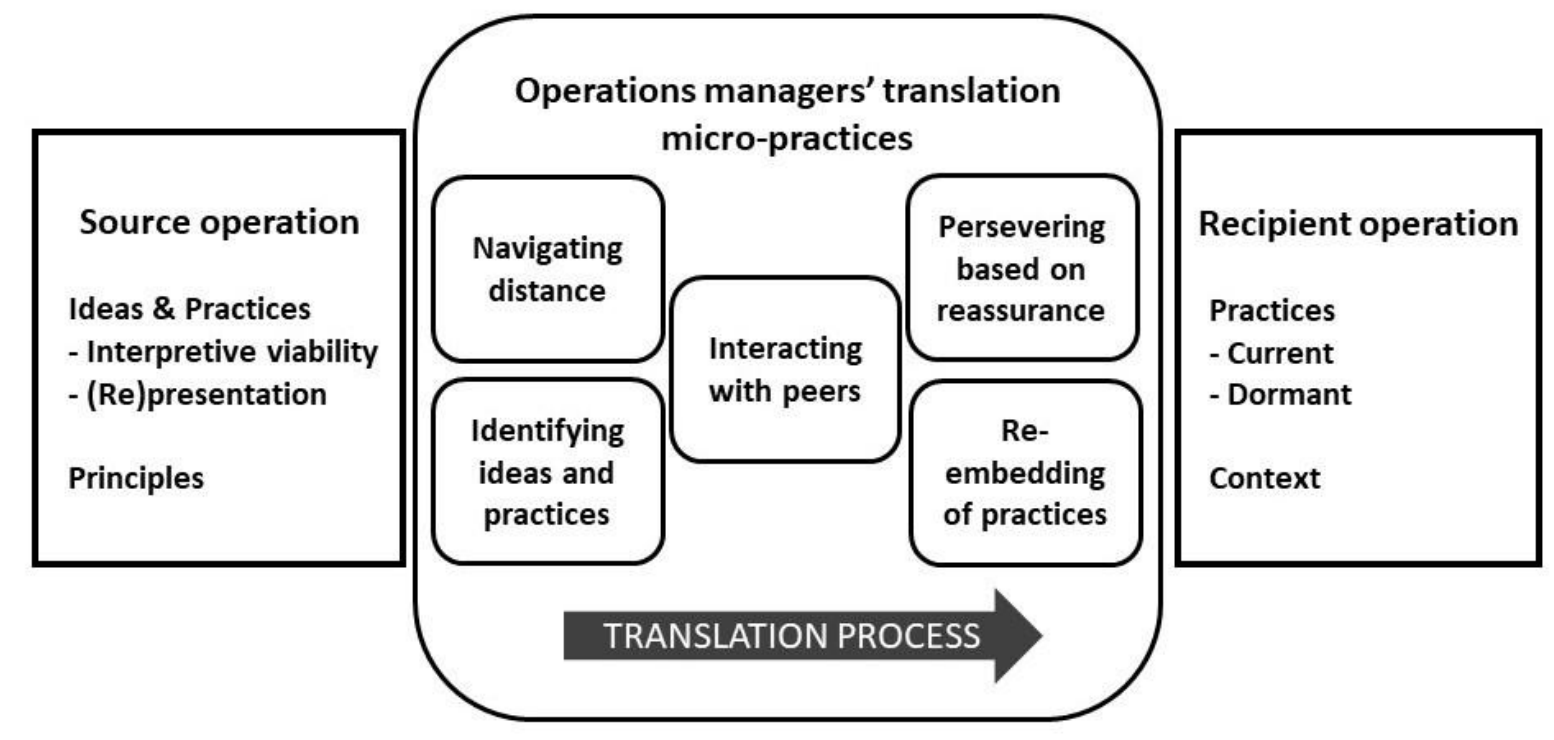

Figure 1 - A framework for operations managers' translation micro-practices 


\section{Discussion}

OM contingency theory research seeks to prescribe how practices (which we have termed management ideas) should be chosen for adoption (Sousa and Voss 2008). However, noting that many organisations adopt ideas that apparently do not fit, in contingency terms, Sousa and Voss argue that OM scholars need to "study in more depth the process of selection of best practices' (Sousa and Voss 2008: 711). That is, to some extent, what we have done in this paper (albeit that we would not use the term 'selection'). In conjunction with relevant concepts from the management ideas and translation literatures, our data have allowed us to reveal some of the practices of operations managers in the translation process.

\subsection{The operations manager as translator}

Our main concern is to understand how a translation perspective can provide alternative insights into the adoption of management ideas in an OM context. The data reveal that operations managers are much more active in the process of adoption, through their role as translators, than typically portrayed in the OM practice contingency research (Sousa and Voss 2008), or in literature that identifies critical success factors (e.g. Wali, Deshmukh, and Gupta 2003; Salaheldin 2009) for the adoption of new ideas. The latter leaves the operations manager strangely absent: many of the typical critical success factors are outside the ambit of OM altogether (e.g. 'top management support', 'employee training') or somewhat distanced from the OM substance of the ideas and practices (e.g. 'customer orientation'). In some respects, our analysis resonates with existing translation literature that focusses on the micropractices and roles of middle managers in translation (Radaelli and Sitton-Kent 2016), but also offers additional insights, some of which arise because we focussed on operations managers in particular. 
It is often operations managers who occupy what Huising (2016: 384) calls the "noman's land' (at least as far as researchers are concerned) between 'macro patterns of diffusion and micro processes of organisational change'. Operations managers are not full-time agents of change or internal consultants, charged with implementing management ideas by getting other people to adopt them; rather, they have to use and live with the ideas and practices that are translated. In this sense, they are not generic middle managers, but have a more specific and distinctive perspective on and relationship to many of the management ideas and practices they encounter. Furthermore, it is evident from the data that our managers are not only active translators, but also often see themselves as the object of change: they are the ones who will 'communicate better', improve their leadership, or emulate inspirational leaders whom they encounter, for example. This indeed is a process by which, potentially, 'a new actor is created' (Czarniawska and Joerges 1996) as part of translation, as well as ideas and practices being translated. (This is so in two senses - the manager may change his/her own practices as a result of the translation process, but also come to be understood by others as holding a different role or identity by virtue of being associated with the translated idea and the translation process.)

The five micro-practices we identify are distinctive by virtue of being those of operations managers. So, while any middle manager might navigate distance somewhat as we have described, an operations manager has a particular understanding of his or her own firm's operations, as a basis for both assessing and mitigating the effects of distance. In a similar way, when identifying management ideas and practices, operations managers can make judgments about which of these will be consistent with, or a valuable addition to, the existing operation. Their intimate understanding of their operation allows them to categorise what they observe, because their OM experience helps them to recognise it, and to feel able to discard elements or adapt others. Just as the inexperienced traveller may prefer a package 
holiday to buying each element separately, a more general manager may feel more need to import the management idea in its entirety, possibly simplified (Morris and Lancaster 2006), and with less active translation. But as Sahlin-Andersson (1996: 92) puts it, 'the ability to maintain and form local practices is not mainly found in the choice between institutions [ideas] but rather in the editing of models and concepts.' Once again, this differs from the account in OM practice contingency research of managers who look out at the available options among management ideas, then select and adopt one (Sousa and Voss 2008). These first two micro-practices, as Figure 1 suggests, all entail the operations manager moving mentally back and forth between her own operation and the one she is observing or interacting with - source or peer - comparing and evaluating differences and similarities, at varying degrees of abstraction.

Peer interaction deserves special attention because of the particular circumstances of the study. It includes facets of the appropriation of the translation role as described by Radaelli and Sitton-Kent (2016), but was given a distinctive focus because the peers were usually other operations managers, which affected the topics on which they exchanged views and information. It is also salient that our managers interacted with peers outside their own firms. This provides the benefits of insights from dis-interested peers, who have no concerns about 'turf protection' such as may arise between peers from within the same firm (cf Balogun and Johnson 2004) and could thus share their views and ideas more freely. Peer interaction also allows identity work. Radaelli and Sitton-Kent (2016) see an important part of the appropriation of the translation role as forming an identity in relation to the translation process (see also van Grinsven, Sturdy, and Heusinkveld 2020); the literature suggests that identity work can involve experimenting with 'provisional selves' (Ibarra 1999). In SMEs, managers may have few if any peers. The external peer network in our setting nevertheless allowed that experimentation to take place, with the business school environment providing an 'identity 
workspace' (Petriglieri and Petriglieri 2010), away from the everyday work environment. Huising (2016) also examines peer groups, but hers are groups of peers united by the very management idea that they seek to promulgate, BPR. In our set-up, the peer groups are united around a more general set of issues: their role and identity as operations managers, productivity improvement, and employee engagement.

Our novel notion of persevering, based on reassurance, also depends to some extent on the particular expertise of the operations manager. Making judgments about particular practices or aspects of performance in the large firms requires the ability to 'see the wood for the trees' in the large firms' processes, as discussed above. It also requires a high level of familiarity with operations within the manager's own firm to make the judgment whether they are, in important respects, as good as those observed in ostensibly best-practice exemplars. This suggests a relational aspect to editing and translation - managers interpreting the practices and management ideas in the source organisation in relation to those already adopted in their own SME. Managers in would-be recipient firms can pay attention to and evaluate aspects of external practices but, rather than using them to change what they do in their own firms, they use them as reference points against which to judge - and, where appropriate to judge as satisfactory or superior - their own practices. In other words, the translation process can result in a positive decision to stay the same. Our data also show 'story-telling' processes: the story that SME managers and their staff perpetuate that they as an SME (relative to external, assumed-to-be-successful firms) 'are terrible....have this issue, have that issue...'; or the story that the SME manager brings back from their encounter with the large firm, which shows their own firm in a good light. And, in this story-telling process, the managers are also forming their own identity in relation to knowledge sources and the practices within their own firms (cf van Grinsven, Sturdy, and Heusinkveld 2020). 
Because we concentrated on the operations managers' interaction with the source rather than the recipient organisations (i.e. their own), we have data on which ideas or practices were re-embedded, but less insight into the process of re-embedding. In terms of content, most of the practices adopted seem to relate to communications with the operations staff. Communication is, of course, important for any manager. However, our data suggest that the operations managers' dominant topics of communications are performance measurement and reporting, and production planning \& control. This echoes the view of Huising (2016: 388) that '[w] hat circulates is not a canned practice or fundamental idea, "but rather accounts and materializations of a certain idea or practice" (Sahlin and Wedlin 2008: 225)'. Alternatively, in some instances, quite generic ideas travelled without any concrete or particularly fine-grained instantiation: to re-quote one of our interviewees, 'it's just presenting information in a really simple way. That ultimately is all that was needed'. At the same time, what is embedded as practice in the recipient firm may be an amalgam of 'little nuggets' of more specific practices observed and assimilated.

\subsection{Effective OM translation}

While our main aim is to understand and theorise the translation practices of operations managers, we can also begin to develop some more prescriptive insights from our study. In so doing, we draw on Røvik's instrumental approach to translation, to help to understand how operations managers can more effectively play their part in translation. This is partly a function of the managers' translation competence, partly of the context. 'Translation competence' is defined as 'the ability of translators to translate practices and ideas between organizational contexts in ways that increase the probability of achieving organizational ends' (Røvik 2016: 299). Røvik argues that translation competence depends on understanding the management idea, knowing the recipient context, and applying the most appropriate 
'translation rules' (Røvik 2019). The broad rules are: copying; addition and omission; and alteration. In brief, these depend on (a) the features of the source and (b) the features of the relationship between recipient and source (Røvik 2016: 300). An effective translating agent, then, needs to read these contingencies to determine the extent to which to use different rules. For example, a practice that is more explicit, less complex and less embedded should be translated using copying, which seeks to replicate the source practice. Where there is significant dissimilarity between recipient and source context, omission and addition are appropriate translation rules (this is effectively part of our notion of 'navigating distance'). For the reasons we have discussed above, operations managers are uniquely well-placed to judge salient features of the ideas and practices, and of the source and recipient contexts, when operations-based ideas and practices are under consideration. This should come as no surprise, but such considerations are absent from the way that OM contingency theory treats these issues: it has nothing to say about the fundamental nature of the ideas or practices, nor about the relationship between the source and the recipient, only considering 'fit' between the management idea and recipient context. Bringing to the surface their translation micropractices and then beginning to be more explicit about applying the translation rules may offer a way for operations managers more consistently, deliberately - and perhaps legitimately - to play effective, active roles in bringing new ideas and practices into their operations.

\section{Conclusions, implications and limitations}

This research makes several theoretical, practitioner and policy contributions. First, we show that operations managers play a much more active role in translating management ideas and practices from outside their own firms than is portrayed in the OM practice contingency literature. Second, we identify five translation micro-practices of operations managers, which 
draw on existing ideas in translation theory, but extend these and take into account the particular functional position and expertise of the operations manager. Third, we develop a simple framework (Figure 1) that captures these micro-practices, but also places them in the interactive translation process in which the operations manager engages.

The research has practical implications. Senior managers should, when seeking to implement deliberate programmes of improvement, take account of the way operations managers translate operations-oriented management ideas: apparently well-intentioned managers in our study edited ideas extensively and had little interest in the representational trappings of the ideas and practices they encountered. This may be especially important when engaging external agents of change such as consultants (cf Wright 2019) to instigate such changes. For operations managers, Røvik’s proposals for an instrumental approach to translation (Røvik 2019) suggest that operations managers can develop their translation competence by understanding and applying the translation rules of copying and modification. For both senior managers and operations middle managers, our data also show the potential benefits of direct visits to exemplar sites alongside the more abstract exposure to management ideas, and the value of peer networks of some kind.

This research also has policy implications. Government initiatives to improve productivity, particularly those that seek to exploit 'spillover' or 'diffusion' effects, need to take account of the extent to which and the ways in which management practices (perhaps in contrast to technological advances) are constantly edited, adapted, re-named (Morris and Lancaster 2006) and re-contextualised as they are translated from firm to firm. As such, research and evaluation that asks - particularly in SMEs - questions such as 'do you use lean?' may be wide of the mark: firms may have adopted many of the practices that such approaches entail, but have eschewed the terminology and overarching systemic character promulgated by consultants. In other words, they may be doing a lot of lean things (those 
most relevant to them) but not be aware (or care) that that is how they might be categorised by some external observers. Policy makers should also take note of the mechanisms by which some aspects of diffusion and spillover actually take place: ideas do not travel according to inviolable physical laws (as the metaphors of 'diffusion' and 'spillover' might suggest), but depend on the particular connections and interactions between firm and non-firm actors in a particular industrial system, which is sometimes termed the 'institutional architecture' (Spring et al. 2017).

The research inevitably has limitations. The firms we investigated were SMEs. For the reasons we set out (see also Kull et al. (2018)), SMEs are tremendously important in their own right, but we are also aware that their size and structures may present distinctive patterns and processes of translation, and of the operations manager's role in it, that are not replicated in larger firms. We chose - also for reasons explained above - to concentrate on the disembedding or idea acquisition part of the translation process. This means that, although we have indications of practices that the SME managers have brought into their own firms, we do not have long-run data on how the practices were re-embedded, nor whether they actually led to improved performance. Further research could examine the re-embedding process in more depth, possibly using related concepts such as resourcing and issue-selling (HowardGrenville 2007; Wiedner, Barrett, and Oborn 2017) to understand the internal politics of change. At the level of micro-practices, it would be interesting to use Beynon-Davies and Lederman's (2017) concept of second-order affordance to understand how the re-embedding of such tools as whiteboards may lead to changes well beyond their immediate context, since what may appear to be 'cherry-picked', low-level practices may, in fact, have wider implications for organisational roles, identities, routines and processes. 


\section{Acknowledgements}

The authors would like to acknowledge the cooperation of the managers who allowed us to accompany them on the programme, and to interview them. We also acknowledge the cooperation of those involved in running the programme and hosting the visits to large firms, and Lancaster University Management School for funding the fieldwork. Kostas Selviaridis read and commented helpfully on earlier drafts: the usual caveats apply. We also thank the four anonymous reviewers for spirited and constructive comments on earlier versions, and the Associate Editor for his valuable guidance.

\section{References}

Andrews, Dan, Chiara Criscuolo, and Peter N Gal. 2016. "The best versus the rest: the global productivity slowdown, divergence across firms and the role of public policy." In OECD Productivity Working Papers. Paris: OECD Publishing.

Ansari, Shahzad M, Peer C Fiss, and Edward J Zajac. 2010. "Made to fit: How practices vary as they diffuse." Academy of management review 35 (1):67-92.

Balogun, Julia, and Gerry Johnson. 2004. "Organizational restructuring and middle manager sensemaking." Academy of Management Journal 47 (4):523-49.

Benders, Jos, and Kees Van Veen. 2001. "What's in a fashion? Interpretative viability and management fashions." Organization Science 8 (1):33-53.

Benders, Jos, and Sander Verlaar. 2003. "Lifting parts: putting conceptual insights into practice." International Journal of Operations \& Production Management 23 (7):75774.

Beynon-Davies, Paul, and Reeva Lederman. 2017. "Making sense of visual management through affordance theory." Production Planning \& Control 28 (2):142-57.

Bloom, Nicholas, Benn Eifert, Aprajit Mahajan, David McKenzie, and John Roberts. 2013. "Does management matter? Evidence from India." The Quarterly Journal of Economics 128 (1):1-51.

Bloom, Nicholas, and John Van Reenen. 2010. "Why do management practices differ across firms and countries?" The Journal of Economic Perspectives 24 (1):203-24.

Boaden, Ruth J 1997. "What is total quality management... and does it matter?" Total Quality Management 8 (4):153-71. 
Braun, Virginia, and Victoria Clarke. 2006. "Using thematic analysis in psychology." Qualitative Research in Psychology 3 (2):77-101.

Chang, Daesung, and Sang M. Lee. 1996. "The impact of critical success factors of JIT implementation on organizational performance." Production Planning \& Control 7 (3):329-38.

Clarke, Victoria, and Virginia Braun. 2017. "Thematic analysis." The Journal of Positive Psychology 12 (3):297-8.

Cohen, W. M., and D. A. Levinthal. 1990. "Absorptive capacity: a new perspective on learning and innovation." Administrative Science Quarterly 35:128-52.

Cornelissen, Joep P, and Mirjam D Werner. 2014. "Putting framing in perspective: A review of framing and frame analysis across the management and organizational literature." The Academy of Management Annals 8 (1):181-235.

Czarniawska, B, and B. Joerges. 1996. "Travels of ideas." In Translating organizational change, edited by B. Czarniawska and G. Sevòn, 13-48. Berlin: de Gruyter.

Dubois, A., and L.-E. Gadde. 2002. "Systematic combining: an abductive approach to case research." Journal of Business Research 55:553-60.

Holweg, Matthias. 2007. "The genealogy of lean production." Journal of Operations Management 25 (2):420-37.

House of Commons. 2018. "Small businessees and productivity." In.: House of Commons Business, Energy and Industrial Strategy Committee, Fifteenth Report of Session 201719, HC 807.

Howard-Grenville, Jennifer A 2007. "Developing issue-selling effectiveness over time: Issue selling as resourcing." Organization Science 18 (4):560-77.

Huising, Ruthanne. 2016. "From adapting practices to inhabiting ideas: How managers restructure work across organizations." In The structuring of work in organizations, 383-413. Emerald Group Publishing Limited.

Ibarra, Herminia 1999. "Provisional selves: Experimenting with image and identity in professional adaptation." Administrative Science Quarterly 44 (4):764-91.

Ketokivi, Mikko A, and Roger G Schroeder. 2004. "Strategic, structural contingency and institutional explanations in the adoption of innovative manufacturing practices." Journal of Operations Management 22 (1):63-89.

Kull, Thomas J, Josip Kotlar, and Martin Spring. 2018. "Small and Medium Enterprise Research in Supply Chain Management: The Case for Single-Respondent Research Designs." Journal of Supply Chain Management 54 (1):23-34.

Lane, P. J., and M. Lubatkin. 1998. "Relative absorptive capacity and interorganizational learning." Strategic Management Journal 19 (5):461-77. 
Latour, Bruno 1984. "The powers of association." The Sociological Review 32 (1_suppl):26480.

Lewin, Arie Y, Silvia Massini, and Carine Peeters. 2011. "Microfoundations of internal and external absorptive capacity routines." Organization Science 22 (1):81-98.

Lillrank, Paul 1995. "The transfer of management innovations from Japan." Organization Studies 16 (6):971-89.

Mantere, Saku 2008. "Role expectations and middle manager strategic agency." Journal of Management Studies 45 (2):294-316.

Mantere, Saku, and Mikko Ketokivi. 2013. "Reasoning in organization science." Academy of management review 38 (1):70-89.

Mol, Michael, Julian Birkinshaw, and Nicolai J Foss. 2019. "The system of management ideas." In The Oxford Handbook of Management Ideas, edited by Andrew Sturdy, Stefan Heusinkveld, Trish Reay and David Strang, 25-41.

Morris, Timothy, and Zoë Lancaster. 2006. "Translating management ideas." Organization Studies 27 (2):207-33.

Negrão, Léony Luis Lopes, Moacir Godinho Filho, and Giuliano Marodin. 2017. "Lean practices and their effect on performance: a literature review." Production Planning \& Control 28 (1):33-56.

OECD. 2015. The future of productivity. Paris: OECD.

Olhager, Jan. 2002. "Supply chain management: A just-in-time perspective." Production Planning \& Control 13 (8):681-7.

Petriglieri, Gianpiero, and Jennifer Louise Petriglieri. 2010. "Identity workspaces: The case of business schools." Academy of Management Learning \& Education 9 (1):44-60.

Phillips, Nelson, Graham Sewell, and Steve Jaynes. 2008. "Applying critical discourse analysis in strategic management research." Organizational Research Methods 11 (4):770-89.

Prahalad, Coimbatore K, and Richard A Bettis. 1986. "The dominant logic: A new linkage between diversity and performance." Strategic Management Journal 7 (6):485-501.

Radaelli, Giovanni, and Lucy Sitton-Kent. 2016. "Middle managers and the translation of new ideas in organizations: A review of micro-practices and contingencies." International Journal of Management Reviews 18 (3):311-32.

Rogers, EM. 2003. Diffusion of innovations. New York: Free Press.

Romero-Silva, Rodrigo, Javier Santos, and Margarita Hurtado. 2018. "A note on defining organisational systems for contingency theory in OM." Production Planning \& Control 29 (16):1343-8. 
Røvik, Kjell-Arne. 2019. "Instrumental understanding of management ideas." In The Oxford Handbook of Management Ideas, 121-37. Oxford: Oxford University Press.

Røvik, Kjell Arne 2016. "Knowledge transfer as translation: Review and elements of an instrumental theory." International Journal of Management Reviews 18 (3):290-310.

Sahlin-Andersson, Kerstin. 1996. "Imitating by editing success. The construction of organizational fields and identities." In Translating organizational change, edited by B Czarniawska and G. Sevòn, 69-92. Berlin: de Gruyter.

Sahlin, Kerstin, and Linda Wedlin. 2008. "Circulating ideas: Imitation, translation and editing." In The Sage handbook of organizational institutionalism, edited by Royston Greenwood, Christine Oliver, Roy Suddaby and Kerstin Sahlin-Andersson, 218-42. London: Sage.

Salaheldin, Salaheldin Ismail. 2009. "Critical success factors for TQM implementation and their impact on performance of SMEs." International Journal of Productivity \& Performance Management 58 (3):215-37.

Schonberger, R. J. 1986. World Class Manufacturing. New York, NY: Free Press.

Shrivastava, R. L., R. P. Mohanty, and R. R. Lakhe. 2006. "Linkages between total quality management and organisational performance: an empirical study for Indian industry." Production Planning \& Control 17 (1):13-30.

Soltani, Ebrahim, Bradley Barnes, Jawad Syed, and Ying-Ying Liao. 2012. "Does management's approach impede service quality?" Production Planning \& Control 23 (7):523-40.

Sousa, Rui, and Christopher A. Voss. 2008. "Contingency research in operations management practices." Journal of Operations Management 26 (6):697-713.

Spring, Martin. 2017. "Operations management." In The Oxford handbook of management, edited by Adrian Wilkinson, Steven J Armstrong and Michael Lounsbury, 57-80. Oxford University Press.

Spring, Martin, Alan Hughes, Katy Mason, and Paul McCaffrey. 2017. "Creating the competitive edge: A new relationship between operations management and industrial policy." Journal of Operations Management 49:6-19.

Sturdy, Andrew , Stefan Heusinkveld, Trish Reay, and David Strang. 2019. "Researching management ideas: an introduction." In The Oxford Handbook of Management Ideas, edited by Andrew Sturdy, Stefan Heusinkveld, Trish Reay and David Strang, 1-22. Oxford: Oxford University Press.

Teece, D. J., Gary Pisano, and Amy Shuen. 1997. "Dynamic capabilities and strategic management." Strategic Management Journal 18 (7):509-33.

van Grinsven, Marlieke, Stefan Heusinkveld, and Joep Cornelissen. 2016. "Translating management concepts: towards a typology of alternative approaches." International Journal of Management Reviews 18 (3):271-89. 
van Grinsven, Marlieke, Andrew Sturdy, and Stefan Heusinkveld. 2020. "Identities in translation: Management concepts as means and outcomes of identity work." Organization Studies (In press):0170840619866490.

Van Maanen, John, Jesper B. Sörensen, and Terence R. Mitchell. 2007. "The interplay between theory and method." Academy of management review 32 (4):1145-54.

Voss, CA, and SJ Robinson. 1987. "Application of just-in-time manufacturing techniques in the United Kingdom." International Journal of Operations \& Production Management 7 (4):46-52.

Wæraas, Arild, and Jeppe Agger Nielsen. 2016. "Translation theory 'translated': Three perspectives on translation in organizational research." International Journal of Management Reviews 18 (3):236-70.

Wali, Ayoob A, SG Deshmukh, and AD Gupta. 2003. "Critical success factors of TQM: a select study of Indian organizations." Production Planning \& Control 14 (1):3-14.

Werr, Andreas, and Peter Walgenbach. 2019. "Management techniques." In The Oxford Handbook of Management Ideas, edited by Andrew Sturdy, Stefan Heusinkveld, Trish Reay and David Strang, 104-20. Oxford: Oxford University Press.

Wiedner, Rene, Michael Barrett, and Eivor Oborn. 2017. "The emergence of change in unexpected places: Resourcing across organizational practices in strategic change." Academy of Management Journal 60 (3):823-54.

Womack, J. P., D. T. Jones, and D. Roos. 1990. The machine that changed the world. New York: Rawson Associates.

Wright, Christopher. 2019. "Thought Leaders and Followers." In The Oxford Handbook of Management Ideas, edited by Andrew Sturdy, Stefan Heusinkveld, Trish Reay and David Strang, 141-58. Oxford: Oxford University Press.

Zhang, Min, Wei Wang, Thong Ngee Goh, and Zhen He. 2015. "Comprehensive Six Sigma application: a case study." Production Planning \& Control 26 (3):219-34.

Zhu, Qinghua, Yihui Tian, and Joseph Sarkis. 2012. "Diffusion of selected green supply chain management practices: an assessment of Chinese enterprises." Production Planning \& Control 23 (10-11):837-50. 
Appendix 1-Data structure

FIRST-ORDER OBSERVATIONS

MICRO-PRACTICES

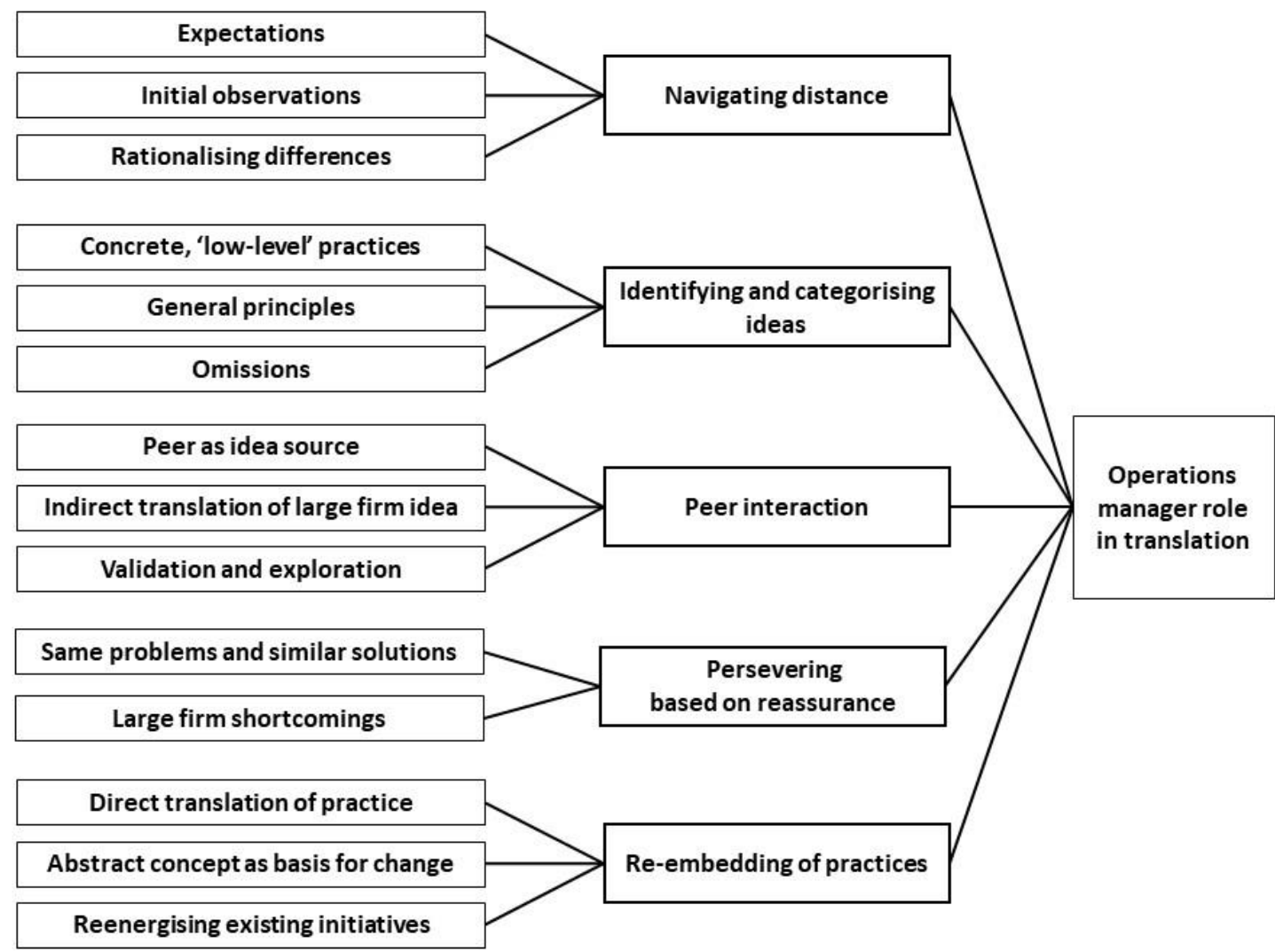

